\title{
Intact Stability Analysis of Crew Boat with Variation of Deadrise Angle
}

\author{
Teguh Putranto ${ }^{1}$, Ketut Suastika ${ }^{2}$, Julhari Gunanta ${ }^{3}$
}

\begin{abstract}
As a supporter of offshore supply logistics operations, crew boat moving in high speed needs the hull design that is able to reduce the resistance but the stability is still good. The innovation of hull design carried out have to consider not only in aspect of safety and comfort, but also in aspect of cargo hold capacity. Therefore, this research will analyze the change of deadrise angle to the stability, cargo hold capacity, and resistance. The shift of weight and buoyancy point caused by the change of deadrise angle is calculated by block method. The calculation of cargo hold is carried out by integration of CSA curve. The calculation of ship stability is carried out by using the Krylov I method. If the stability varied by deadrise angle does still fulfill, the next analysis is the resistance. The resistance calculation uses Computational Fluid Dynamics (CFD). The smallest resistance is occurred with deadrise angle 16 degrees which the magnitude is $144.741 \mathrm{kN}$ in speed 24 knots. The output obtained from this research is a recommendation of hull design revealing that crew boat with deadrise angle 6 degrees have an enough cargo hold to take up payload and the stability still fulfills the IMO Regulation.
\end{abstract}

Keywords - offshore, crew boat, deadrise angle, stability, resistance, IMO regulation.

\section{INTRODUCTION}

Ship hull design innovation is needed in order to obtain the minimum ship resistance. The hull forms changed will significantly affect either the ship resistance or the ship stability when the underwater hull form is modified. Interaction between fluid and structure will influence the ship behaviour moreover the wave effect is added. The ship stability evaluation could describe whatever ship has stable, unstable, or neutral condition [1].

One of the hull form design innovation is to change the deadrise angle that it will affect the resistance and stability of ship. But, it needs to be also considered about the volume of cargo hold caused by the change of deadrise angle [2]. The deadrise angle is measured in midship section that can be shown in Figure 1.

The hull form at the immersed part affects the magnitude of ship resistance. Moreover, when the ship moves in high speed, it will definitely increase the resistance. The slenderer of hull form, the smaller resistance of ship. If the resistance of ship is small, the main engine power will can be reduced. But, the stability have to be checked, in addition the resistance. Usually, the small resistance is occurred in the great deadrise angle. The interaction between fluid and hull will

Teguh Putranto is with Department of Naval Architecture and Shipbuilding Engineering, Sepuluh Nopember Institute of Technology, Surabaya, 60111, Indonesia. E-mail: theories@ na.its.ac.id

Ketut Suastika is with Department of Naval Architecture and Shipbuilding Engineering, Sepuluh Nopember Institute of Technology, Surabaya, 60111, Indonesia. E-mail: k_suastika@na.its.ac.id

Julhari Gunanta is with Department of Naval Architecture and Shipbuilding Engineering, Sepuluh Nopember Institute of Technology, Surabaya,60111, Indonesia. E-mail: julharigunanta@gmail.com produce the resistance and the Froude number indicating the parameter of ship speed will also affect the magnitude of resistance [3]

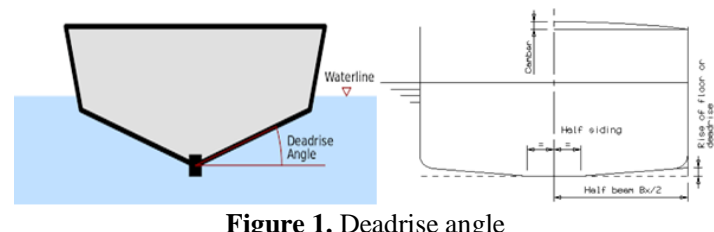

The ship stability evaluation is carried out using International Maritime Organization (IMO) Regulation emphasizing in the statics and dynamics ship stability calculation in the intact condition. During the calculation have fulfilled this regulation, the ship is declared safe to be operated. Excitation force experiencing by the ship stable will turn the position of ship [4]. The ship response could induce sea-sickness and even ship capsized so that it is needed to be analyzed [5].

Theoretically, the metacentre position, the intersection between buoyancy force direction and centreline, is as parameter of the stability of ship. The ship will capsize if the metacentre position is negative it means that the metacentre point is below gravity point [6].

\section{METHOD}

Briefly, the methodology of this research encompasses the analysis of weight and buoyancy point, volume of cargo hold, and intact ship stability. The flowchart of this research can be shown in Figure 2. DA is the acronym of Deadrise Angle.

A. Weight and Buoyancy Point

The deadrise angle of existing ship is 11 degrees. Then, this angle is varied into 6 and 16 degrees. The deadweight and lightweight of ship varied by the deadrise angle could be calculated by dividing ship into blocks representing the ratio between weight and volume of ship.

\section{B. Volume of Cargo Hold}

Using the integration of CSA curve, the volume of cargo hold is obtained. Equation 1 shows the integration CSA curve to obtained the volume of cargo hold.

$V=\int A(x) d x$

where $\mathrm{V}$ is the volume of cargo hold and $\mathrm{A}(\mathrm{x})$ is the Cross Section Area (CSA) curve. 


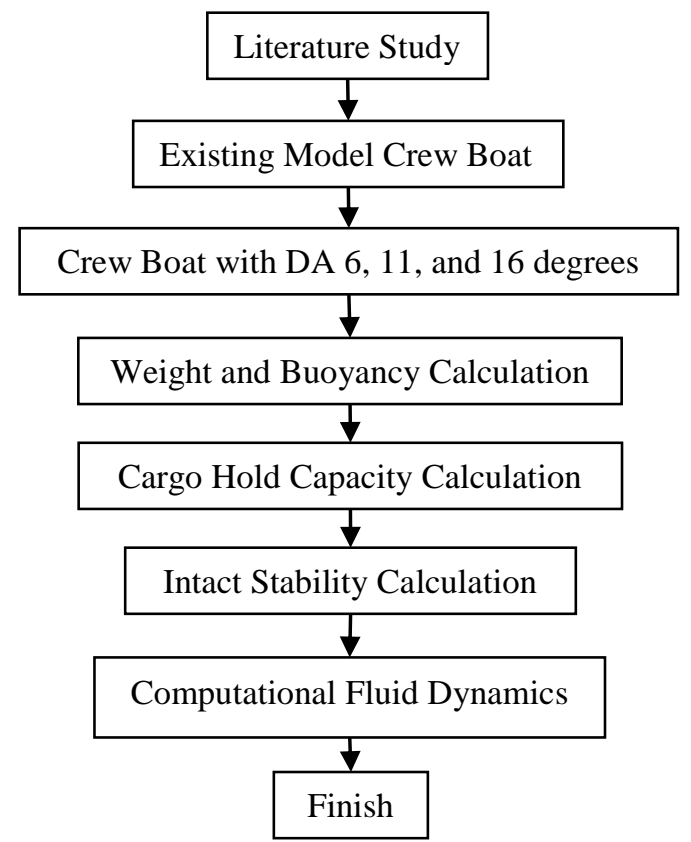

Figure 2. Flowchart

\section{Intact Ship Stability Analysis}

The ship stability analysis is carried out using numerical method which the Krylov I formula is one of the method and equation used to solve the stability problem. Equation 2 shows a formula to calculate the static stability.

$$
l=\int M G d \theta
$$

where 1 is the righting arm of static stability that shows the distance of gravity to buoyancy direction perpendicularly. And $\theta$ (theta) is the heel angle started 0 to 90 degrees.

\section{Computational Fluid Dynamics}

Fluid flow in this numerical method uses some of assumptions. Fluid is incompressible which it will not be influenced by temperature. Computational Fluid Dynamics applies Navier-Stokes equation that can be shown in Equation 3.

$$
\rho\left|\frac{\partial V}{\partial t} \_+v \cdot \nabla v\right|=-\nabla p+\mu \nabla^{2} v+f
$$

The method for solving Equation 3 uses Finite Volume Method (FVM) which this method is developed by the finite difference method. This method is usually used to solve the differential equation. Generally, algorithm numerical had by finite difference method is an integral of fluid flow control equation.

\section{RESULTS AND DISCUSSION}

\section{A. Intact Ship Stability}

Figure 3 shows the lines plan of crew boat for this research. The existing design is varied based on the deadrise angle consisted of 6,11 , and 16 degrees that can be shown in Figure 4. Table 1 shows that the most lightweight is at 6 degrees. The Longitudinal Centre of Gravity (LCG) and Keel to Gravity (KG) can be known from the hydrostatics curve.

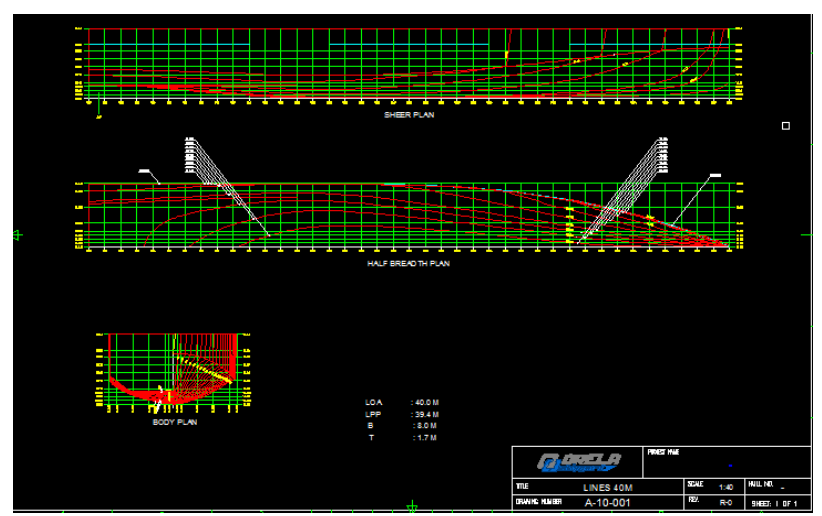

Figure 3. Lines plan of crew boat at the existing model (deadrise angle 11 degrees)

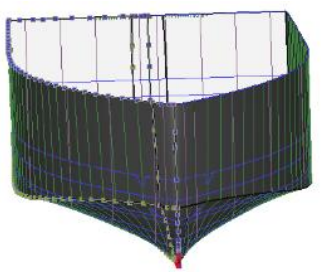

(a)

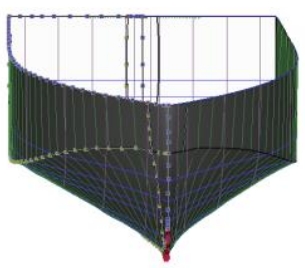

(b)

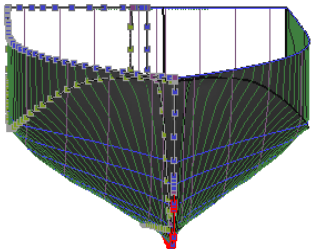

(c)

Figure 4. The variation of deadrise angle, (a) 6 degrees; (b) 11 degrees; (c) 16 degrees

TABLE 1.

THE LIGHTWEIGHT, LCG AND KG WITH VARIATION OF DEADRISE

\begin{tabular}{|c|c|c|c|}
\hline $\begin{array}{c}\text { Deadrise Angle } \\
\text { (degree) }\end{array}$ & $\begin{array}{c}\text { LWT } \\
\text { (ton) }\end{array}$ & $\begin{array}{c}\text { LCG from } \\
\text { midship (m) }\end{array}$ & $\begin{array}{c}\text { KG } \\
\text { (m) }\end{array}$ \\
\hline 11 & 99.001 & -4.041 & 2.708 \\
\hline 16 & 98.059 & -3.844 & 2.734 \\
\hline 6 & 101.409 & -4.012 & 2.446 \\
\hline
\end{tabular}

There is a relation between Longitudinal Centre of Buoyancy (LCB) and LCG so that the ratio of its can be converted to calculate LCB.

By the change of deadrise angle, the volume of cargo hold will change. The design is modelled from keel to main deck so that the change of cargo hold will change the volume of cargo hold. Table 2 shows that the difference volume of cargo hold to existing model. The volume of cargo hold will affect the displacement in the same draft.

TABLE 2.

THE VOLUME OF CARGO HOLD (CG) WITH THE VARIATION OF DEADRISE ANGLE

\begin{tabular}{|c|c|c|c|}
\hline $\begin{array}{c}\text { Deadrise Angle } \\
\text { (degree) }\end{array}$ & $\begin{array}{c}\text { Volume } \\
(\mathrm{m} 3)\end{array}$ & $\begin{array}{c}\text { Difference to } \\
\text { Existing (\%) }\end{array}$ & Information \\
\hline 11 (existing) & 585.601 & & \\
\hline 6 & 629.365 & $7 \%$ & Increase the CG Volume \\
\hline 16 & 475.181 & $18 \%$ & Decrease the CG Volume \\
\hline
\end{tabular}


Based on the IMO Chapter 4.5.7 "Loading Condition", the load case of supply vessel is consisted of:

1. In departure, vessel is full load;

2. In arrival, vessel is full load, but fuel oil is $10 \%$;

3. In departure, vessel is empty load, no ballast, but provision and fuel oil is full;

4. In arrival, vessel is empty load, full ballast, but provision and fuel oil is $10 \%$.

TABLE 3.

THE STABILITY CALCULATION OF DEADRISE ANGLE 11 DEGREES

\begin{tabular}{|c|c|c|c|c|c|c|}
\hline \multirow{2}{*}{ Parameter } & \multicolumn{4}{|c|}{ Load Case } & \multirow{2}{*}{$\begin{array}{c}\text { IMO } \\
\text { Requirement }\end{array}$} & \multirow{2}{*}{ Units } \\
\hline & 1 & 2 & 3 & 4 & & \\
\hline Area $0-15$ & 0.618 & 0.651 & 0.586 & 0.651 & $\geq 0.055$ & m.rad \\
\hline Area $0-30$ & 0.183 & 0.182 & 0.158 & 0.182 & $\geq 0.03$ & m.rad \\
\hline Area $30-40$ & 1.120 & 1.105 & 0.933 & 1.105 & $\geq 0.2$ & m.rad \\
\hline Righting Arm & 46.400 & 47.300 & 47.300 & 47.300 & $\geq 15$ & deg \\
\hline $\mathrm{GM}_{0}$ & 2.914 & 3.326 & 3.136 & 3.326 & $\geq 0.15$ & $\mathrm{~m}$ \\
\hline
\end{tabular}

Table 3 shows that the stability calculation is presented in each of load case. The area under the curve means the dynamics stability which all of load case fulfil the IMO requirement. The righting arm for each load case is greater than the IMO requirement. It means that the crew boat will not capsize for example the righting arm of load case 1 is 46.6 degrees means that the condition of ship capsize is at that value.

Figure 5 shows the summary of righting arm in each load case. The greatest righting arm is at the load case 1 where the righting arm is $1.11 \mathrm{~m}$ at 50 degrees. When the ship is at the full load condition, the ship is more stable than other load cases.

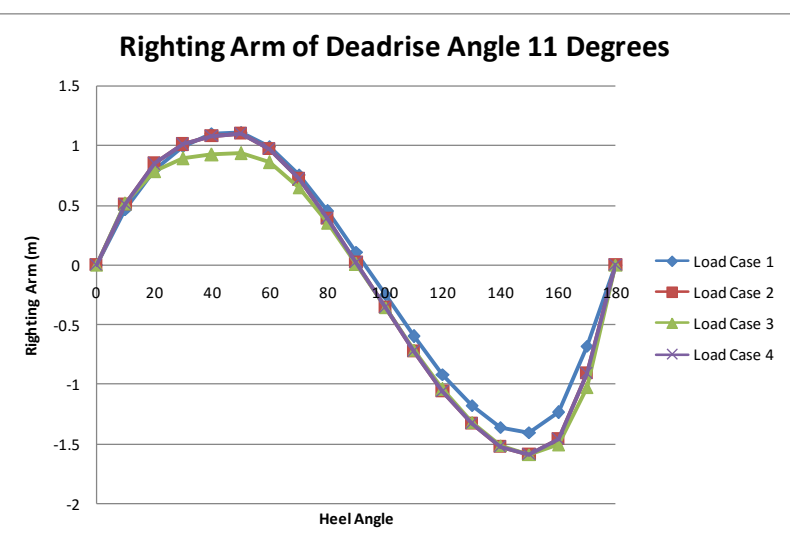

Figure 5. The graph of righting arm for each load case in deadrise angle 11 degrees

Table 4 shows the summary of stability calculation of deadrise angle 6 degrees. The area under the curves still fulfils the IMO requirement. The greatest righting arm is at the load case 1 where the righting arm is $1.173 \mathrm{~m}$ at 50 degrees, it means that the load case 1 is more stable than other load cases. By the same token, Figure 6 shows the curve of righting arm.

TABLE 4.

THE STABILITY CALCULATION OF DEADRISE ANGLE 6 DEGREES

\begin{tabular}{|c|c|c|c|c|c|c|}
\hline \multirow{2}{*}{ Parameter } & \multicolumn{4}{|c|}{ Load Case } & \multirow{2}{*}{$\begin{array}{c}\text { IMO } \\
\text { Requirement } \\
\end{array}$} & \multirow{2}{*}{ Units } \\
\hline & 1 & 2 & 3 & 4 & & \\
\hline Area $0-15$ & 0.662 & 0.649 & 0.417 & 0.417 & $\geq 0.055$ & m.rad \\
\hline Area 0-30 & 0.199 & 0.205 & 0.179 & 0.179 & $\geq 0.03$ & m.rad \\
\hline Area 30-40 & 1.189 & 1.193 & 1.035 & 1.035 & $\geq 0.2$ & m.rad \\
\hline Righting Arm & 45.500 & 42.700 & 31.800 & 31.800 & $\geq 15$ & deg \\
\hline $\mathrm{GM}_{0}$ & 3.109 & 3.762 & 4.552 & 4.552 & $\geq 0.15$ & $\mathrm{~m}$ \\
\hline
\end{tabular}

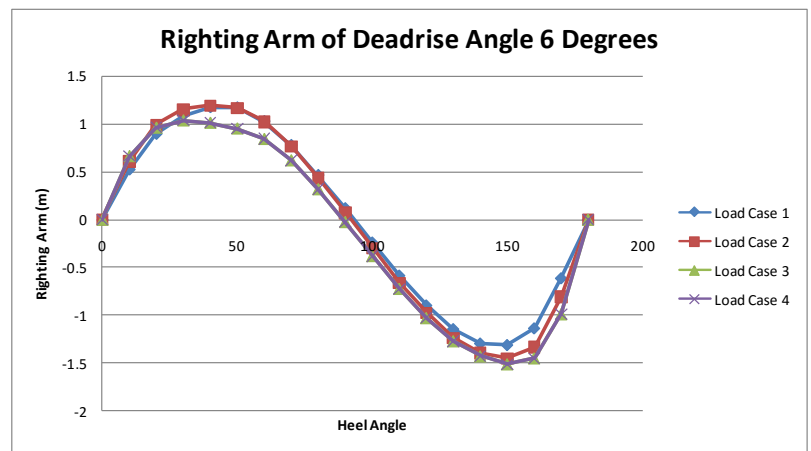

Figure 6. The graph of righting arm for each load case in deadrise angle 6 degrees

TABLE 5.

THE STABILITY CALCULATION OF DEADRISE ANGLE 16 DEGREES

\begin{tabular}{|c|c|c|c|c|c|c|}
\hline \multirow{2}{*}{ Parameter } & \multicolumn{4}{|c|}{ Load Case } & \multirow{2}{*}{$\begin{array}{c}\text { IMO } \\
\text { Requirement }\end{array}$} & \multirow{2}{*}{ Units } \\
\hline & 1 & 2 & 3 & 4 & & \\
\hline Area 0-15 & 0.574 & 0.609 & 0.576 & 0.609 & $\geq 0.055$ & m.rad \\
\hline Area $0-30$ & 0.170 & 0.161 & 0.143 & 0.161 & $\geq 0.03$ & m.rad \\
\hline Area 30-40 & 1.073 & 1.058 & 0.957 & 1.058 & $\geq 0.2$ & m.rad \\
\hline Righting Arm & 47.300 & 50.000 & 51.800 & 50.000 & $\geq 15$ & $\operatorname{deg}$ \\
\hline $\mathrm{GM}_{0}$ & 2.217 & 2.215 & 2.107 & 2.215 & $\geq 0.15$ & $\mathrm{~m}$ \\
\hline
\end{tabular}

Table 5 and Figure 7 have same pattern and result when the deadrise angle 6 and 11 degrees. The conclusion of all deadrise angle is that the stability is accepted in IMO requirement.

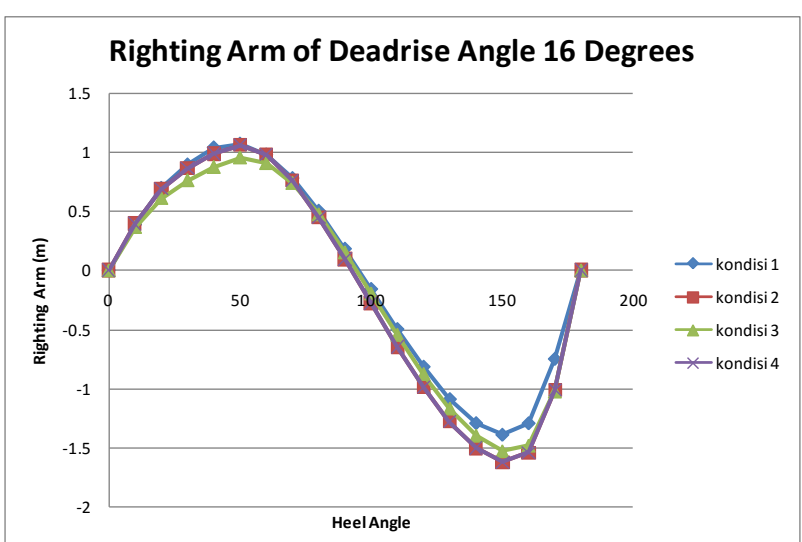

Figure 7. The graph of righting arm for each load case in deadrise angle 16 degrees

\section{B. Ship Resistance}

The ship resistance can be shown from the CFD result. The existing model that deadrise angle is 11 degrees is ever carried out the experiment in Laboratory of Hydrodynamics ITS. This result is compared with numerical calculation obtained from CFD which can be shown in Figure 8.

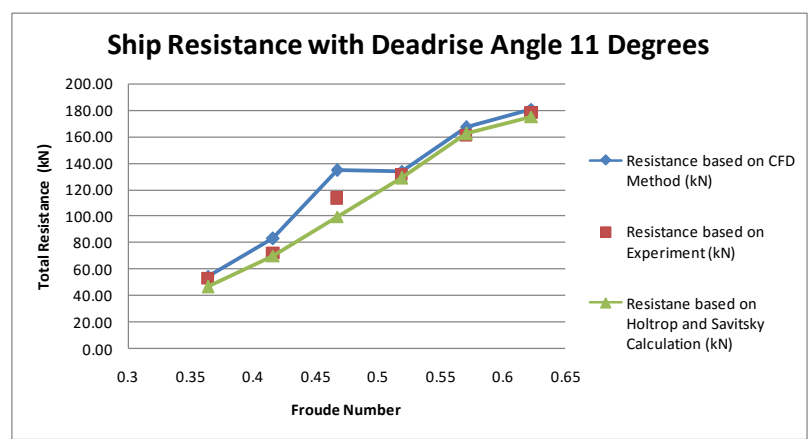

Figure 8. The graph shown total resistance and Froude number with CFD, experiment, and holtrop-savitsky calculation 
When ship moves in slow speed, the holtrop calculation can be used. But, in the high speed, the savitsky calculation is able to provide the result of ship resistance. Figure 10 can be shown that the result of each method have same pattern. The resistance in high speed is greater than in low speed.

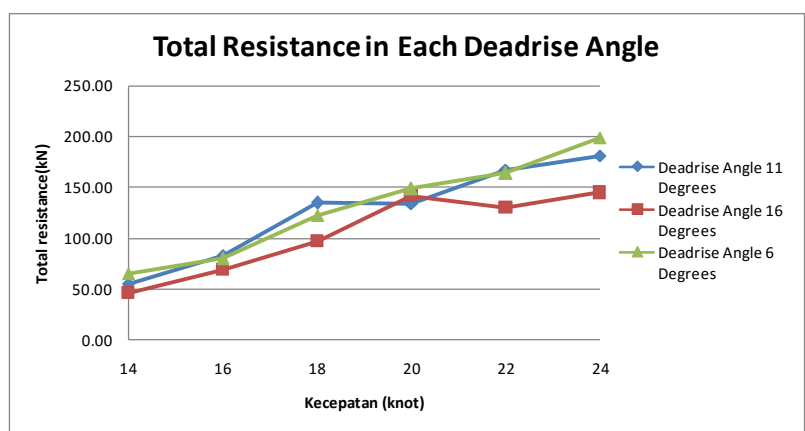

Figure 9. The total resistance in each deadrise angle based on holtrop and savistsky calculation

From the Fig. 8 above shows the comparison of the value of total resistance on the model with the rise of floor angle 11 degrees obtained from CFD methods, of experimentation and calculation methods Holtrop and Savitsky. Resistance values obtained from CFD method is generally greater when compared with experiment and calculation method Holtrop and Savitsy. At a speed of 14 knots (Fr 0.364), for example where the difference between the value of total resistance Based on CFD methods with experimental reached $3.5 \%$ while the Holtrop method reaches $14 \%$. At maximum speed is 24 knots (Fr 0.623) the difference in value of total resistance by CFD methods with experiments by $1.65 \%$ while the difference between the total resistance CFD methods and Savitsy at $3.23 \%$. The difference in the value of total resistance occurs at a speed of 18 knots (Fr 0.467), namely the difference between the CFD methods with experimental reached $15 \%$ while the difference between CFD methods with methods of calculation Savitsky reached $20 \%$. It can be concluded that Savitsky calculation have small error and same pattern with the experimental that can be shown in Figure 9. Savitsky method is appropriate to be used for planning hull meaning that suitable for high speed ship.

\section{CONCLUSION}

From this research, the conclusion can be obtained as follows :

1. The volume of cargo hold is reduced by $7 \%$ if the deadrise angle is diminished by 5 degrees. The volume of cargo hold is increased by $18 \%$ if the deadrise angle is enhanced by 5 degrees.

2. For the three hull form based on variation of deadrise angle, those still fulfill the criteria of IMO Regulation A.749 (18) Chapter 4.5 "Intact Stability Code, Offshore Supply Vessel" at each of loadcase.

3. For the full load ship, the righting arms are $1.176 \mathrm{~m}$, $1.097 \mathrm{~m}$, and $1.037 \mathrm{~m}$ for deadrise angle 6, 11, and 16 degrees respectively.

4. The deadrise angle 16 degrees has the small resistance compared to the other two variations.

\section{ACKNOWLEDGEMENTS}

Author would like to express thank you for LPPM ITS for funding and support through Pemula Grant 2016. For laboratory hydrodynamics staff, author also expresses thank you for the cooperation in completing this research.

\section{REFERENCES}

[1] S. Aktar, G. Saha, K. Alim, "Drag Analysis of Different Ship Models Using Computational Fluid Dynamics Tools", The International Conference on Marine Technology, MARTEC 2010, Dhaka, Bangladesh, 2010.

[2] S. Harvald, 1992, "Tahanan dan Propulsi Kapal (Terjemahan)", Airlangga Press, Surabaya.

[3] F. Lakitosh, "Analysis of Ship and Plate Vibrations Caused by Wave Forces", A Dissertation Submitted to the Faculty of College of Engineering and Computer Science, Florida Atlantic University, 2012

[4] R. Bhattacharyya, "Dynamics of Marine Vehicles", John Wiley and Sons, New York, USA, 1978.

[5] G. A. Bonaschiand O. Filatova, "Identification of a Response Amplitude Operator for Ship", Mathematics-in-Industry Case Studies Journal, Volume 5, pp. 1-26, 2013

[6] T. Putranto and A. Sulisetyono, "Analisa Numerik Gerakan dan Kekuatan Kapal Akibat Beban Slamming Pada Kapal Perang Tipe Corvette", Jurnal Ilmu Pengetahuan dan Teknologi Kelautan, Vol. 12, No. 3, Universitas Diponegoro, 2015. 